\title{
The Impact of Consumer-Based Brand Equity on Word-of-Mouth Behavior
}

\author{
Laradi Sofiane, Ph.D. \\ Professor of Marketing \\ Blida 2 University - Lounici Ali (Algeria) \\ Faculty of Economics, Business and Management Sciences
}

\begin{abstract}
This study aims to fulfill two theoretical gaps; proposing an integrated model that consists of components and consequence of brand equity. We first categorize brand equity in four principal and different perspectives that have been addressed by academics: firm, consumer, integrated, and internal perspective. Second we theorize consumerbased brand equity as four continuum dimensions (i.e. awareness, perceived quality, social image, emotional attachment) as sources which could generate a positive consumer behavior responses (i.e. Word Of Mouth behavior). A survey method was conducted to assess the predictive ability of CBBE sources. The result shows that brand awareness, perceived quality, social brand image, and brand emotional attachment all together constitute a value added by the brand to the product, and all dimensions contribute positively and significantly to WOM behavior as expected.
\end{abstract}

Keywords: brand equity perspectives, awareness, perceived quality, social image, emotional attachment, Word of mouth.

\section{Introduction}

Branding is a fundamental decision in products strategy, perhaps the most distinctive skill of professional marketers is their ability to create, maintain, protect, reinforce and enhance brands. Basically, a brand is a name, term, sign, symbol, design or a combination of these, which is used to identify the goods or services of one seller or group of sellers and to differentiate them from those of competitors (Kotler et al, 1999). Currently more advanced concepts in branding management, the companies eventually learn that the power related to the control of brand strength that perform in the value delivered to the customer. Brand strength reflects the central concept of brand equity. Brand equity has been an issue of increasing importance in recent years due to the effects achieved by brand value, the presumption is building a strong brand yields a number of marketing advantages (Hoeffler \& Keller, 2003).

Understanding how brand equity source are created and how they influence consumer behavior is thus a research priority (Keller \& Lehman 2006). Turning to customer-based brand equity as source of intangible advantage, it is claimed that the conceptualization and operationalization of customer-based brand equity is somewhat largely fragmented. Brand equity has been defined in a number of different ways for many different purposes (Christodoulides \& Chernatony, 2010). It is apparent that customer-based brand equity has been conceptualized as multidimensional construct in individual-level (Aaker, 1996 ; Lassar et al, 1995 ; Yoo et al, 2001 ; Netemeyer et al, 2004 ; Atilgan et al, 2009), and that all dimensions of brand equity are relatively important and found to be positively correlated (Kayaman \& Arasli, 2007; Goi \& Chieng, 2011), however, it is noted that there is no general agreement in current marketing literature as to the nature and content of these dimensions. Specifically, there is no many studies include or one study indicates the presence of symbolic or emotional features to express the essence of brand value, even though the importance of this kind of dimensions on currently consumer choice as an alternative [or complementary] to the cognitive model of choice (Elliot, 1998).

Brand advantages can be manifested in many different ways. A strong brand can have an impact on aspects of consumer behavior in various ways. Across two different brand of categories (brand services and brand product), CobbWalgren et al (1995) demonstrate that the brand with greater advertising budget yielded substantially higher levels of brand equity. In turn, the brand with the higher equity generates significantly greater preferences and purchase intentions. Credibility is key element of brand equity that enhances perceived quality and reduces perceived risk and cost information (Erdem \& Swait, 1998; Erdem., Swait \& Valenzuela, 2006). Furthermore, a strong brand may have an impact on companies' financial results in various ways. The sources of brand equity (i.e., attribute-based and non attribute-based components) have good predictive validity on market share premium and price premium (Park \& Srinivasan, 1994). 
Despite the recognition of several marketing advantages of strong brand, there is no study addressing the impact of the brand equity on word of mouth behavior. Thus, this study identifies two gaps in brand equity literature: the non attendance of emotional aspects as valuable information for the measurement of customer based brand equity, and how they affect Word Of Mouth behavior.

This study aims to fulfill two theoretical gaps by proposing an integrated model that consists of components and consequence of brand equity, the contribution of this study is to incorporate two important aspects in understanding brand equity from consumer perspective. First, we attempt to conceptualize and measure consumer-based brand equity by including symbolic and emotional feature in the model. Second, we attempt to test the predictive validity of consumer-based brand equity on Word-of-mouth (WOM) as the most powerful behavior outcome.

To accomplish the above stated objectives, this study organized in the following manner: first, we submit a brief literature review of conceptualization and measurement of consumer-based brand equity which are reported in the marketing literature. Second, we present the research model and the hypotheses. Third, we present the research methodology and results. Fourth, this section includes the discussion followed by limitations, managerial implications and future research.

\section{Brand equity: A review}

The concept of brand equity is well documented but it has not seen a comprehensive and united agreement. We can notice a very extensive literature attempting to conceptualize the brand equity construct as summarized in several recent publications (Changeur, 2002; Christodoulides \& Chernatony, 2010). The brand equity concept has been mentioned in more than one of the previously analyzed models brand equity as defined by Farquhar (1989). Farquhar (1989) defined brand equity as the added value with which a given brand endows a product. This definition steals the most conclusions of all previous studies. Other definitions have appeared and take more than one tendency. Lassar et al (1995) operationalize brand equity as the enhancement in the perceived utility and desirability a brand name confers on a product. It is the consumers' perception of the overall superiority of a product carrying that brand name when compared to other brands. As well, Brand equity defined as the difference in consumer choice between the focal branded product and an unbranded product given the same level of product features (Yoo et al, 2000; Yoo \& Donthu 2001). Brand equity also defined as incremental utility (Park \& Srinivasan, 1994), and as total expected utility (Erdem \& Swait, 1998; Erdem et al, 2006). Likewise, Brand equity is defined as a set of brand assets and liabilities linked to a brand, its name and symbol that add to or subtract from the value provided by a product or service to a firm and/or to that firm's customers (Aaker, 1991).

We can observe four principal and different based perspectives that have been taken by academics to study brand equity: firm, consumer, integrated, and internal perspective.

\subsection{Firm perspective of brand equity}

Firm-based perspective of brand equity use the accounting value-based techniques, and is financially based motivation to estimate the value of a brand more precisely for accounting purposes (in terms of asset valuation for the balance sheet) or for merger, acquisition, or divestiture purposes. Several different methods of brand valuation have been suggested. Simon and Sullivan (1990) define brand equity in terms of the incremental discounted future cash flows that would result from a product having its brand name in comparison with the proceeds that would accrue if the same product did not have that brand name. Based on the financial market value of the company, their estimation technique extracts the value of brand equity from the value of a firm's other assets. Ailawadi et al (2003) have proposed revenue premium as a measure of brand equity, revenue premium defined as the difference in revenue (i.e., net price $\mathrm{X}$ volume) between a branded good and a corresponding private label. Walliser (2001) illustrates the diversity of existing methods, and argues that despite the importance of using such techniques still finding how to create a strong brand in market is missing.

There is a great deal of published research on brand equity; most of it deals either with struggling to value brand equity as financial asset or with trying to understand more about the construct structure for marketing drives.

\subsection{Marketing perspective of brand equity}

Consumer-based brand equity use the marketing construct as value determined through a variety form of consumerbrand rapport at individual analysis (Changeur, 2002). Those approaches that provide individual-level (or segmentlevel) measures of brand equity yield measures of brand equity in utilities rather than in financial terms, which is less meaningful to marketing managers and corporate decision makers given the growing call for better accountability and metrics in marketing (MSI, 2004). 
The measurement of brand equity from consumer perspective has two basic approaches, direct and indirect approach (Keller, 1993). The indirect approach attempts to assess potential sources of customer-based brand equity by measuring brand knowledge (i.e., brand awareness and brand image). The direct approach attempts to measure customer-based brand equity more directly by assessing the impact of brand knowledge on consumer response (e.g., preferences, choice) to different elements of the firm's marketing program. The indirect and direct customer-based brand equity measuring approaches are complementary and should be used together.

The conceptualization of consumer-based brand equity have mainly derived from cognitive psychology (Keller, 1993 ; Chen, 2001 ; Krishnan, 1996 ; Changeur \& Dano, 1996) combined with behavior perspective (Kamakura \& Russell, 1993 ; Swait \& Erdem, 1998 ; Yoo et al, 2000 ; Atilgan et al, 2009).

Customer-based brand equity occurs when the consumer is aware of the brand and holds some favorable, strong and unique brand associations in memory (Keller, 1993). Krishnan (1996) uses a memory network model to identity various measures (or associations and characteristics) underlying consumer-based brand equity. An empirical study found that a set size, valence, uniqueness, and origin of associations are the mean differences between high and low brand equity.

\subsection{Integrative perspective of brand equity}

To sum up, comprehensive perspectives incorporate both approaches; customer-based brand equity and firm-based brand equity. The combined approach has emerged to make up for the insufficiencies that may exist when only one of the two understandings is emphasized. Dyson et al. (1996), for instance, describes a survey research system designed to relate a financial brand value to the consumer-based equity expressed by images and associations. Motameni and Shahrokhi (1998) proposed a global brand equity valuation, which combine brand equity from the marketing perspective and brand equity from the financial perspective. The results of Kim et al (2003) study imply that strong underlying dimensions of brand equity (i.e., brand loyalty, perceived quality, brand image) can cause a significant increase in revenue of hotel firms, and a lack of brand equity can damage the potential sales flow and income over time.

\subsection{Internal perspective of brand equity}

In this perspective, brand value is the ability of company to generate positive employees perceptions toward a brand they should deliver accordingly to the consumers expectations, this value resulted from internal brand management, and ultimately generates a high organization benefits.

Despite the academics and practitioners alike promoting the positive outcomes of employees being aware of the organization's brand in the context of their work environment, there appears to be no evidence thus far to understand the impact of such brand building efforts from an employee perspective. The internal perspective of brand equity becoming increasingly important in services field. Marketing is being encouraged to move from a goods-dominant view towards a customer centric and service-dominant view, in which intangibility, exchange process and relationships are central.

The employee Based Brand Equity (EBBE) can be defined as the differential effect that brand knowledge has on an employee's response to their work environment, requires the translation of the brand identity in a way that is meaningful to the employee in the context of their roles and responsibilities, as such, internal brand management has taken on increased prominence, given the pivotal role that employees play in the value brand deliverance (Grace \& King, 2009). This conceptualization provides another means by which to model brand equity and seeks to expand on existing theory. The model proposes three key areas upon which the process of establishing EBBE can be understood (i.e. internal brand management practices, brand knowledge effects and internal brand management benefits) (see Grace \& King, 2009).

\section{Research background}

This study attempt to incorporate two important aspects in understanding consumer-based brand equity through conceptualizing and measuring consumer-based brand equity, and through testing the predictive validity of consumer based brand equity on Word-of-mouth (WOM) as behavior response.

Most researchers describe customer-based brand equity as a multidimensional concept (Lassar et al, 1995, Keller, 1993). Several empirical studies on the dimensions of customer-based brand equity (e.g, Cobb- Walgren et al, 1995; Yoo and Donthu, 2001; Pappu et al, 2005) are all derived from Aaker (1991) and Keller (1993) frameworks where brand equity can be measured by four constructs: brand awareness, brand association, perceived quality and brand loyalty. 
In this study, customer-based brand equity is conceptualized in accordance not only to brand knowledge based largely on cognitive psychology (Keller, 1993 ; Keller, 2003), but integrates also emotional model choice (Elliot, 1998). In this study, customer-based brand equity is also proposed as a multidimensional construct, but comprises four continuum components: brand awareness, perceived quality, social image, and emotional attachment. Clearly, brand managers should aim to build lasting positive beliefs in the consumer's mind and lasting positive affective in the consumer's heart in order to create the positive differential responses of the consumers toward the brand in question.

\subsection{Brand awareness}

Brand awareness is a key component of brand equity (Aaker, 1996; Keller, 2003; Yoo and Donthu, 2001; Pappu et al, 2005). It is defined as an individual's ability to recall and recognize a brand (Keller, 1993). Brand awareness reflects the salience of the brand in the customers mind, Recognition, Recall, Top-of-mind, brand dominance, Brand Knowledge and Brand Opinion are other levels included by Aaker (1996) in measuring awareness. Awareness can affect customers' perceptions and attitudes toward a specific brand, which can lead to brand choice and eventually to brand loyalty (Aaker, 1996). Brand awareness is defined as a rudimentary level of brand knowledge involving, at the least, recognition of the brand name, and the brand awareness may have considerable effect on consumer choice (Hoyer \& Brown, 1990).

\subsection{Perceived quality}

Perceived quality is considered as one of the main elements of brand equity across CBBE frameworks (Aaker, 1996, Dyson et al, 1996, Keller, 1993). Perceived quality is defined by Zeithaml 1988 in his seminal work as consumer's judgment about a product's overall excellence or superiority. Perceived quality differs from objective quality. Perceived product quality is a global assessment characterized by a high abstraction level and refers to a specific consumption setting (Zeithaml, 1988). Perceived quality is the customer's judgment of the overall excellence, esteem, or superiority of a brand (with respect to its intended purposes) relative to alternative brand(s). This definition has gained some level of acceptance (Netemeyer et $a l, 2004)$. Perceived quality is one kind of brand association (Chen, 2001). Low and Lamb 2001 conceptualize brand image (includes functional and symbolic perceptions), brand attitude (overall evaluation of a brand), and perceived quality (judgments of overall superiority) as promising dimensions of brand associations. However, the perceived quality of product is central to the theory that assumes "strong brands add value to consumers" purchase evaluations". Zeithaml (1988) asserts that perceived quality can act as a key influencing factor in determining consumer's choices.

\subsection{Social image}

Despite the advanced of marketing studies in brand image concept still the subject of many researchers because this concept contains several faces and interfaces explained and dominated by the psychological aspects. Brand image is not less important than other marketing variables, but getting more importance in immaterial dominated market where symbolic and emotional dimensions overcome consumer evaluation and behavior. Consumer decision is often directed toward the symbols expressed by the product (or brand more specifically), is not always directed toward the functions as it used to be. This view is list under the assumption that individuals buy things not only for what they can do (i.e. functional performance), but also for what they mean (i.e. symbolic performance) (see Levy, 1959). Studies from different stream of research show the relative importance of social perception toward a brand in individual evaluation and behavior. In consumer research, Dunning (2007) argues that consumer behavior might similarly be designed to enhance positive self-views and then discusses the potential role played by these self-image motives in recently documented consumer behavior phenomena (e.g., endowment, compensation, affirmation, and licensing effects). More specific, consumers achieve meaning in their lives through the joint experience of a brand with friends in a brand community, and beyond the personal brand significance, social relationships comprise important vehicles of symbolic meaning (Morandin et al, 2013). In CBBE research, Lassar et al (1995) limits the image dimension to the social dimension (i.e., social image), and define social image as the consumer's perception of the esteem in which the consumer's social group holds the brand. It includes the attributions a consumer makes and a consumer thinks that others make to the typical user of the brand. Brand social image is brand value-adding when brand personality and style are well regarded by society. Guizani and Valette-Florence (2008) consider the social value is primarily a research for identification and social recognition of individual through the modes of consumption. In other words, social seeking value behind brand consumption motivated both by "self-orientation" and "social-orientation".

\subsection{Emotional attachment}

Academic researchers and practitioners in marketing have shown a significant interest in studying consumers' attachment to brands. Park et $a l$, (2010) define brand attachment as the strength of the bond connecting the brand with the self. 
The same researchers argue the existence of two critical factors reflect the conceptual properties of brand attachment: brand-self connection (involves the cognitive and emotional connection between the brand and the self) and brand prominence (reflects the salience of the cognitive and affective bond that connects the brand to the self). Thomson et al, (2005) develop a three-factor model characterizes brand attachment in terms of three emotional components: affection, passion, and connection. Brand emotional attachment is strong psychological and emotional relationship, sustainable and interactive between consumer and the affective brand, and would explained by two factors: dependency and friendship bond (Cristau, 2001).

Brand attachment offers value over brand attitude strength in predicting consumers' intentions to perform difficult behaviors, actual purchase behaviors, brand purchase share, and need share (Park et al, 2010). When established, emotional brand attachment is a powerful tool for building CBBE and influencing the purchasing decisions.

In summary, there are four dimensions of CBBE. The four CBBE dimensions constitute the hypothesis 1 in the current research. Consumer-based brand equity is nearly always represented as a multidimensional construct consisting of various concepts.

Hypothesis 1: There are four dimensions of CBBE: brand awareness, perceived quality, Social image, and emotional attachment.

\subsection{Word-Of-Mouth behavior}

Marketing practitioners and theorists routinely cite the power of the personal referral on customer behavior, Word-ofmouth (WOM) is more influential on behavior than other marketer controlled sources (for example advertising) in raising awareness, generating positive attitudes, and purchase decisions, because personal sources are viewed as more trustworthy (Buttle, 1998). WOM communication, informal communications directed at other consumers about the ownership, usage, or characteristics of particular goods and services and/or their sellers (Westbrook, 1987), has recently receive a renewed attention in the marketing literature. WOM communication can be very influential in any purchase decision; previous research suggests that is particularly important for services based on customer-employee relationships (Gremler et $a l$, 2001). WOM behavior is the way how consumer response to dissatisfaction (Richins, 1983). WOM behavior is the informal exchange of information between consumers about a brand, without the sender being formally rewarded. Teo and Soutar (2012) indicate that despite the role of WOM in influencing choice much better than the role of author forms of marketing communication, the measurement of the WOM construct is a challenge as there is a lack of consensus as to how WOM should be viewed and, consequently, measured. Recent studies have combined WOM's various conceptualizations. Harrison-Walker (2001) suggested that the WOM has twodimensional construct (i.e., WOM activity and WOM praise), WOM activity is the frequency with which a person engages in WOM and the number of people with whom the person engages, while WOM praise is the valence of the WOM comments a person makes about their experiences.

While the potential power of WOM as form of promotion is generally accepted, unfortunately, the links between CBBE constructs and WOM formation may not examined in previous research, and because it is important to understand the generation process of positive WOM, the current study examines the relationship between CBBE dimensions and WOM behavior.

\section{Hypothesis 1: CBBE sources are related positively to Word-of-mouth behavior.}

H.2.1. Brand Awareness is related positively to Word-of-mouth behavior.

H.2.2. Perceived Quality is related positively to Word-of-mouth behavior.

H.2.3. Social Brand Image is related positively to Word-of-mouth behavior.

H.2.4. Emotional Attachment is related positively to Word-of-mouth behavior.

H.2.5. Overall CBBE is related positively to Word-of-mouth behavior.

\section{Research methodology}

This research is explores how symbolic and brand affection are integrated to the CBBE context, as well as investigates the effects of CBBE dimensions on WOM behavior. To explore these issues, a questionnaire is administered to assess the research questions and hypotheses previously stated. The survey provides a quick, efficient, and accurate means of assessing this type of information.

\subsection{Developing measures}

A questionnaire was designed, following a literature review, to determine what items are needed to measure the various factors related to CBBE dimensions, and WOM. Each variable are measured by multi-items using a seven-point Likert scale anchored by (1) strongly disagree and (7) strongly agree. The measurement items for each variable were specifically used in this study were based on constructs measures from prior studies. 
Measurement items were carried in two stages. In the first work were conducted with 107 consumers to purify each dimension by performing reliability analysis to remove items with low item-total correlations (Churchill, 1979). The final version of the questionnaire consisted of the items used in the large scale survey to test hypothesis. Table I. describes the number of items and the reliability of each dimension in final version of retained items (i.e. the result first work analysis).

Table I: First work analysis

\begin{tabular}{|l|c|c|c|c|c|}
\hline & awareness & Perceived quality & $\begin{array}{c}\text { Social } \\
\text { image }\end{array}$ & $\begin{array}{c}\text { Brand } \\
\text { attachment }\end{array}$ & WOM \\
\hline First work & 8 & 9 & 8 & 10 & 8 \\
\hline Good items & $\mathbf{4}$ & $\mathbf{4}$ & $\mathbf{5}$ & $\mathbf{5}$ & $\mathbf{3}$ \\
\hline Cronbach's alpha & $\mathbf{0 , 8 3}$ & $\mathbf{0 , 8 7}$ & $\mathbf{0 , 9 2}$ & $\mathbf{0 , 8 0}$ & $\mathbf{0 , 8 8}$ \\
\hline
\end{tabular}

\subsection{Sampling}

The sample was non-randomly drawn from the population of Algeria consumers of Drinks and Televisions, which represent the population of interest in this research. A total of 800 surveys were distributed in the second stage and 587 valid responses were returned, giving a response rate of 73,3 percent. The high response rate was likely due to one reason: the method of questionnaire administration used is "direct collect questionnaires".

\section{Data analysis}

\subsection{Factor Analysis and Reliability}

A Principal Component Analysis was performed with the items to test the factorial validity of the scale. A series of Exploratory Factor Analyses (EFA) were applied to further purify the measurement indicators; the factor structure of the study model is supported for reliability by the Cronbach's. EFA was chosen to define the theoretical framework for sources of CBBE dimensions. Varimax rotation was employed to the principle components in order to extract factors on the same scale that failed to exhibit significant loading on the construct. This research conducted a strict a priori decision criterion to reject factor loadings of 0.5, and the components with Eigen-value greater than 1.0 were retained. The resulting scale had 16 items individualized for a brand of television (ENIE brand) and soda drink (Hamoud Boualam brand), and they are presented in Appendix 1.

Table II: Results of the Exploratory Factor Analysis

\begin{tabular}{|c|c|c|c|c|c|}
\hline & \multicolumn{4}{|c|}{ Components } & \multirow{2}{*}{ Cronbach's } \\
\hline & Factor 1 & Factor 2 & Factor 3 & Factor4 & \\
\hline Awareness 1 & 0,164 & $\mathbf{0 , 8 3 6}$ & 0,192 & 0,316 & \multirow{4}{*}{0,889} \\
\hline Awareness2 & 0,042 & $\mathbf{0 , 8 9 5}$ & $-0,143$ & 0,035 & \\
\hline Awareness3 & 0,032 & 0,797 & 0,220 & $-0,033$ & \\
\hline Awareness4 & $-0,023$ & 0,900 & $-0,030$ & 0,183 & \\
\hline Perceived Quality1 & 0,460 & $-0,155$ & 0,675 & 0,125 & \multirow{4}{*}{0,892} \\
\hline Perceived Quality2 & 0,225 & 0,042 & 0,919 & $-0,032$ & \\
\hline Perceived Quality3 & 0,164 & 0,147 & 0,914 & 0,090 & \\
\hline Perceived Quality4 & 0,477 & 0,221 & 0,614 & 0,437 & \\
\hline Social image1 & 0,285 & 0,196 & 0,369 & 0,795 & \multirow{3}{*}{0,856} \\
\hline Social image2 & 0,410 & 0,152 & 0,169 & 0,712 & \\
\hline Social image3 & 0,269 & 0,112 & $-0,169$ & $\mathbf{0 , 8 5 4}$ & \\
\hline Emotional attachment1 & 0,780 & 0,217 & 0,290 & 0,250 & \multirow{5}{*}{0,916} \\
\hline Emotional attachment2 & 0,904 & 0,178 & 0,240 & 0,129 & \\
\hline Emotional attachment3 & $\mathbf{0 , 8 3 4}$ & 0,119 & 0,321 & 0,199 & \\
\hline Emotional attachment4 & 0,866 & $-0,041$ & 0,167 & 0,294 & \\
\hline Emotional attachment5 & 0,672 & $-0,136$ & 0,071 & 0,246 & \\
\hline Explained Variance & 26,193 & 20,161 & 19,312 & 15,538 & \\
\hline Total variance Explained & \multicolumn{4}{|c|}{81,204} & \\
\hline KMO index & \multicolumn{4}{|c|}{0,781} & \\
\hline Bartlett signification & \multicolumn{4}{|c|}{0,000} & \\
\hline
\end{tabular}

The analysis reveals that 81.2 percent of the variance is contributed by four factors CBBE sources, and these are defined as follows: Awareness (four items), Perceived Quality (four items), Social Image (three items), and Emotional 
Attachment (five items). Table II shows the EFA results. The results of EFA show that the theoretical model receives an acceptable model fit with Variance Explained $=0,812$ (greater than half), $\mathrm{KMO}=0,781$ (greater than 0,3), Bartlett sign $=0,00$ (less than 0,05). The findings indicate that brand equity, which consists of the four continuum key dimensions of brand perceptions and emotions as expected in our first hypothesis H.1.

Tow items are deleted from Social image dimension, because EFA is used to identify dimensions of scales and factor loadings for each scale item. Items with low factor loadings (less than 0.5) are deleted. The correlations for all variables used in this current study to conceptualize CBBE sources are demonstrated in Table III.

Table III. Correlation Between CBBE Constructs.

\begin{tabular}{|l|c|c|c|c|}
\hline & 1 & 2 & 3 & 4 \\
\hline EBA & $(1,84)$ & $0,352^{* *}$ & $0,617^{* *}$ & $0,719^{* *}$ \\
\hline BAW & & $(1,37)$ & $0,407 * *$ & $0,544^{* *}$ \\
\hline PQ & & & $(1,36)$ & $0,597 * *$ \\
\hline SI & & & & $(1,70)$ \\
\hline
\end{tabular}

EBA Emotional Brand Attachment ; BAW Brand Awareness ; PQ Perceived Quality ; SI Social Image

The value between parenthesis is Standard Deviation

** the Correlation is significant (at 0,01 level)

The finding support the conceptualization of CBBE sources proposed as a multidimensional construct comprising four dimensions as indicated by Hypothesis 1 . The CBBE can be expressed through a mixed continuum of perceptions and emotions brand value at the individual level. For this, the strong CBBE is better understood by requiring at once the strong brand cognitions and the strong brand affections.

\subsection{Regression analysis}

Regression analysis procedures were conducted to evaluate the relationship between CBBE dimensions and WOM behavior and their level of significance. We hypothesize that the greater a brand equity, the greater the WOM behavior will be. We have applied regression analysis and the results showed in Table V.

Table V: Regression Summary of the impact CBBE dimensions on WOM behavior. $(\mathrm{N}=587)$

\begin{tabular}{|c|c|c|c|c|c|c|c|}
\hline & \multicolumn{2}{|c|}{$x^{2}$} & \multicolumn{2}{|c|}{ t test } & \multirow[b]{2}{*}{$\mathrm{R}^{2}$ adj } & \multicolumn{2}{|c|}{ ANOVA } \\
\hline & Factors & Beta & t- value & t- Sig. & & $\mathrm{F}$ & Sig. \\
\hline First relationship effect & BAW &, 453 & 4,191 &, 000 &, 194 & 17,566 &, 000 \\
\hline Second relationship effect & PQ & ,606 & 6,275 &, 000 & ,357 & 39,379 &, 000 \\
\hline Third relationship effect & SI &, 552 & 5,455 &, 000 & ,294 & 29,754 &, 000 \\
\hline Forth relationship effect & EBA & 808 & 11,298 & ,000 & ,647 & 127,655 & 000 \\
\hline Fifth relationship effect & OBE & 810 & 11,372 &, 000 & ,650 & 129,312 &, 000 \\
\hline
\end{tabular}

EBA emotional brand attachment ; BAW brand awareness ; PQ perceived quality ; SI social image ;

OBE Overall Brand Equity is the sum of the four sources (i.e., EBA, BAW, PQ, SI)

Emotional attachment, brand awareness, perceived quality, and social brand image are independent variables and word of mouth behavior is dependent variable.

The first regression model which estimates the predictive relationship between Brand awareness and WOM behavior was statistically significant $\left(\mathrm{F}=17.566 ; \mathrm{R}^{2}\right.$ adj $\left.=.194 ; p=.000\right)$. Regression analysis indicates that brand awareness has significantly positive effect on WOM behavior $(\mathrm{p}=.000<0,05 ; \beta=0.453)$. Thus, H2.1, suggesting that brand awareness is positively related to WOM behavior, was supported.

The second regression model which estimates the predictive relationship between perceived quality and WOM behavior was statistically significant $\left(\mathrm{F}=39.379 ; \mathrm{R}^{2}\right.$ adj $\left.=.357 ; p=.000\right)$. Regression analysis indicates that perceived quality has significantly positive effect on WOM behavior ( $\mathrm{p}=.000<0,05 ; \beta=0.606)$. Thus, H2.2, suggesting that brand awareness is positively related to WOM behavior, was supported.

The third regression model which estimates the predictive relationship between social brand image and WOM behavior was statistically significant $\left(\mathrm{F}=29.754 ; \mathrm{R}^{2}\right.$ adj $\left.=.294 ; p=.000\right)$. Regression analysis indicates that social brand image has significantly positive effect on WOM behavior $(p=.000<0,05 ; \beta=0.552)$. Thus, H2.3, suggesting that brand awareness is positively related to WOM behavior, was supported.

The forth regression model which estimates the predictive relationship between and WOM behavior was statistically significant $\left(\mathrm{F}=127.655 ; \mathrm{R}^{2}\right.$ adj $\left.=.647 ; p=.000\right)$. Regression analysis indicates that emotional brand attachment has significantly positive effect on WOM behavior $(\mathrm{p}=, 000<0,05 ; \beta=0.808)$. Thus, $\mathrm{H} 2.4$, suggesting that emotional brand attachment is positively related to WOM behavior, was supported. 
The fifth regression model which estimates the predictive relationship between overall consumer-based brand equity and WOM behavior was statistically significant $\left(\mathrm{F}=129.312 ; \mathrm{R}^{2}\right.$ adj $\left.=.650 ; p=.000\right)$. Regression analysis indicates that overall CBBE has significantly positive effect on WOM behavior $(\mathrm{p}=, 000<0,05 ; \beta=0.810$ ). Thus, H2.5, suggesting that overall CBBE is positively related to WOM behavior, was supported.

Table VI. Summary Results of Hypotheses

\begin{tabular}{|l|l|l|}
\hline & Hypothesis & Result \\
\hline H.1 & CBBE comprise BAW, PQ, SI, EBA & Supported \\
\hline H.2.1 & BAW influence WOM behavior & Supported \\
\hline H.2.2 & PQ influence WOM behavior & Supported \\
\hline H.2.3 & SI influence WOM behavior & Supported \\
\hline H.2.4 & EBA influence WOM behavior & Supported \\
\hline H.2.5 & OBE influence WOM behavior & Supported \\
\hline
\end{tabular}

\section{Discussion}

Christodoulides and Chernatony (2010) suggested that:

-Brand equity monitor systems should consist of perceptual and motivational factors that can be modeled against consequential behavioral measures.

-Functional, emotional and experiential facets should be considered for inclusion in a brand equity measurement system to truly appreciate the evolving nature of brands.

In response to Christodoulides and Chernatony (2010) practical system to measure brand equity, this study was the first to examine combined cognitive-affective based brand equity, and the first to examine its effect on WOM behavior. The purpose of current study was to identify the consumer-based brand equity factors, to develop an exploratory measurement scale, and to test its predictive power with as such behavior. The results reveal that Consumer-based brand equity combines perceptions and affections-based construct. We contend that all four factors of awareness, perceived quality, social image, and brand emotional attachment should together contribute to consumer-based brand equity.

The result supports past findings. Brand awareness and a set of brand associations are the potential of brand equity (Keller, 1993). The image cannot be assessed by attribute measurement alone, but could include measurement of consumers' perceptions of the value and benefits attainable by using the brand ( $\mathrm{Na}$ et al, 1999), in this line; brand social image is more abstract because it represents the expression of brand as perceived by the people (Lassar et $a l, 1995$ ). Perceived quality is one "core" or "primary" facets of customer-based brand equity (Netemeyer et al, 2004) as proposed by Aaker's studies (e.g. Aaker, 1996). Lassar et al (1995) limit the reference of the image dimension to the social dimension, calling it social image. Social image is value-adding because of the social reputation associated with owning or using a brand. The attachment construct has received only limited attention in the marketing literature (Thomson, 2006; Thomson, MacInnis, \& Park, 2005) and none in brand equity research, but we find that brand attachment explains more than quarter of brand value phenomena. Brand is more than a name or logo; it can also be a set of perceptions and emotions that rose from the direct and indirect consumer experiences with brand. Both tangible and intangible performances are the components of the brand which interact with consumers, and come to be over time more established brand in consumers mind and heart.

If Negative WOM behavior is the way how consumer response to dissatisfaction (Richins, 1983), positive WOM behavior is the way how consumer response to durable brand value. This study add WOM variable as consequence of CBBE to purchase intention and preferences (Cobb-Walgren et al, 1995) and to price premium (Lassar et al, 1995; Netemeyer et al, 2004). We contend that both cognitive and affective consumer-based brand equity is a better way to understand the conditions that facilitate positive WOM behavior, because consumer-based brand equity sources are related positively and significantly to WOM behavior. In this way, WOM behavior is the one marketing advantage of strong brand.

\section{Implications, limitations and future propositions}

Measuring brand equity is a desirable goal for many firms to justify their marketing spending. In this article, we developed and presented a scale to measure consumer-based brand equity through cognitive and affective-based value domination. This scale was developed after two studies in which we initiate scale of 83 items to and purified to a scale of 16 items. The resulting scale was significantly validated to track brand equity level. Such as the relationships proposed above, provide managers with insight as to how to best stimulate such behavior (i.e. WOM behavior). 
Building strong brand contributes to enhance value judgments and increase WOM behavior among potential consumers. One of the major implications of this research is that companies have to manage all of the mix marketing elements in integrative marketing program to enhance brand equity by means of enhancing cognitive and affective dimensions of brand equity to expect positive consumers' responses, and ultimately positive financial returns.

However, this research has several limitations that are common to other study in the marketing literature. Address these limits increase our understanding of competitive and sustainable brand value phenomena.

Extended brands sample: Restricting our study to only two brands confers the most potential limitation in terms of result generalizability on other brands. Future research might include in their investigation more and more of different brands to provide more valid scale.

Longitudinal research design: Collecting data in our study restricts results to one time survey, the development of time-series database and testing the dynamic of brand equity-consumer responses relationship in a longitudinal framework would provides more insight into probable causations (i.e., third part endorsement, brand crisis, program marketing).

Extended CBBE sources: Brand equity is a complex and multi-faceted concept and, as such, it requires to be released through a set of measures rather than a limited or single measure. Including other important dimensions might due to the brand initial designing and to product category nature.

Nomological validity of CBBE-consumers responses relationship: To contribute more in brand equity theory, future research might interest to mediators-moderators variables to explain more deeply CBBE sources and to predict more accurately consumer responses. Placing both moderator and mediator variables within the same causal system helps marketers to make salient to how brand equity operates in mind, heart and consumer behaviors outcomes.

Reciprocal effect of WOM: Word-of-mouth is a critical aspect of building brand equity, because consumers share their likes and experiences with brands to each other. The interactive effect of CBBE and WOM should be examined in future research.

Individual differences: We suggest to future research that understanding the brand equity variation across different demographics characteristics (e.g. male vs. female) may provide interesting insights for branding strategy.

\section{Conclusion}

After reviewing the existing brand equity perspectives, our study is an important first exploration on cognitive-affective construct of CBBE. We stress that consumer-based brand equity comprises a continuum. For scholars, the propositions of the study are clear. For managers, the implications of the study are less clear. The finding gives marketing scholars and practitioners a basis beyond mere intuition for recommending the competitive and sustainable brand equity sources and outcomes.

\section{Appendix 1: Questionnaire}

In the following questionnaire we would like to evaluate the mentioned brand. We would like you to evaluate each statement on a 7-point scale with respect to each mentioned brand. Please list a (7) if you strongly agree with a statement, a (1) if you strongly disagree with a statement, and a (4) if you neither agree nor disagree with a statement.

\section{Brand awareness}

1. I can easily recognize « XYZ brand»

2. I can recall logo and slogan of «XYZ brand»

3. «XYZ brand » is familiar to me

4. I know a lot about «XYZ brand»

Perceived quality

1. «XYZ brand » product is of high quality

2. «XYZ brand » offers high quality attributes

3. « XYZ brand » offers superior quality compared to competing brands.

4. I trust «XYZ brand » product

Social image

1. «XYZ brand » fits my personality

2. «XYZ brand » will be well regarded by my friends

3. I would be proud to own «XYZ brand »

Emotional attachment

1. «XYZ brand » procures me pleasure and happiness

2. I $m$ really attracted by « XYZ brand » 
3. I feel always attached to «XYZ brand »

4. I carry a love feeling toward «XYZ brand»

5. I will be unhappy when I get not «XYZ brand »

Word of mouth

1. I encourage my friends to purchase «XYZ brand »

2. I talk about «XYZ brand » to my friends

3. I share my experiences with «XYZ brand » to others

\section{References}

Aaker, David, A, (1996), Measuring brand equity across products and markets. California Management Review, Vol 38 (Spring), pp.102-120.

Aaker, David. 1991. Managing Brand Equity. The Free Press, New York.

Ailawadi, Kusum L. Lehmann, Donald R. \& Neslin, Scott A. (2003). Revenue premium as an outcome measure of brand equity. Journal of Marketing, Vol.67 (October), pp.1-17.

Arthur Cheng-Hsui Chen, (2001). Using free association to examine the relationship between the characteristics of brand associations and brand equity. Journal of Product \& Brand Management, Vol. 10, Iss: 7 pp. $439-451$

Atilgan, Eda. Akinci, Serkan. Aksoy, Safak \& Kaynak, Erdener (2009) Customer-Based Brand Equity for Global Brands: A Multinational Approach. Journal of Euromarketing, Vol. 18, pp.115-132

Buttle, Francis A. (1998).Word of mouth: understanding and managing referral marketing. Journal of Strategic Marketing, Vol.6, pp.241-254.

Changeur, Sophie \& Dano, Florence. (1998). Les associations valorisées par les consommateurs : une approche perceptuelle du capital-marque. CEROG IAE d'Aix-en-Provence, W.P. No.514, 23p.

Changeur, Sophie. (2002). Le capital-marque : concepts et modèles. Cahier de Recherche, No. 648, CEROG-IAE Aix-enProvence, pp.1-26.

Churchill Jr, Gilbert A. (1979). A Paradigm for Developing better Measures of Marketing Constructs. Journal of Marketing Research, Vol.16 (February) pp.64-73.

Cobb-Walgren, Cathy J., Ruble, Cynthia A \& Donthu, Naveen (1995). Brand Equity, Brand Preference and Purchase Intent. Journal of Advertising, Vol. 24, No.3, (Autumn) pp.25-40.

Cristau, Cécile. (2001). Définition et Mesure et Modélisation de l'Attachement à la Marque avec Deux Composantes : la Dépendance et l'Amitié vis-à-vis d'une Marque. Thèse de Doctorat en Sciences de Gestion, IAE Aix-Marseille 3.

Dunning, David. (2007). Self-Image Motives and Consumer Behavior: How Sacrosanct Self-Beliefs Sway Preferences in the Marketplace. Journal of Consumer Psychology, Vol.17, No.4. pp.237-249.

Dyson Paul., Farr, Andy. \& Hollis, Nigel S. (1996). Measuring and using brand equity. Journal of Advertising Research, Vol.36, (November/December), pp.9-21.

Elliott, Richard (1998). A model of emotion-driven choice. Journal of Marketing Management, Vol. 14, pp.95-108.

Erdem, Tulin \& Swait, Joffre (1998) Brand Equity as a Signaling Phenomenon Journal of Consumer Psychology, Vol. 7, No. 2, pp.131-157.

Erdem, Tülin., Swait, Joffre \& Valenzuela, Ana. (2006). Brands as Signals: A Cross-Country Validation Study. Journal of Marketing, Vol. 70 (January), pp.34-49.

Farquhar, Peter H. (1989). Managing Brand Equity, Marketing Research, Vol.1, (September), pp. 24-33

George Christodoulides \& Leslie de Chernatony. (2009). Consumer-based brand equity conceptualisation and measurement : A literature review. International Journal of Market Research, Vol. 52 Issue 1, pp.43-66.

Goi, Chai Lee \& Chieng, Fayrene Yew Leh. (2011). Customer-based brand equity: A study on interrelationship among the brand equity dimension in Malaysia. African Journal of Business Management, Vol. 5 (30), pp. 11856-11862.

Gremler, Dwayne D., Gwinner, Kevin P \& Brown, Stephen W. (2001). Generating positive word-of-mouth communication through customer-employee relationships. International Journal of Service Industry Management, Vol. 12 Iss: 1, pp.44-59.

Guizani, Haythem, Triguero H, Valette-Florence, Pierre (2008) Development of French Consumer Brand Equity Scale» Advances Consumer Research, Vol.2, pp.198-209.

Harrison-Walker, L.J. (2001). The Measurement of Word-Of-Mouth Communication and an Investigation of Service Quality and Customer Commitment as Potential Antecedents. Journal of Service Research, Vol.4, No.1, pp.60-75.

Hoeffler, Steve. \& Keller, Kevin Lane. (2003). The Marketing Advantages of Strong Brands. Journal Brand Management, Vol. 10, No. 6 (August), pp.421-445.

Hoyer, Wayne D. \& Brown, Steven P. (1990). Effects Of Brand Awareness On Choice For A Common, Repeat-Purchase Product. Journal Of Consumer Research, Vol. 17 (September), pp.141-148

Kamakura, Wagner A. \& Russell, Gary J. (1993). Measuring brand value with scanner data. International Journal of Research in Marketing, Vol.10, No.1, pp.9-22. 
Kayaman, Ruchan \& Arasli, Huseyin (2007). Customer based brand equity: evidence from the hotel industry. Managing Service Quality, Vol. 17, No. 1, pp. 92-109.

Keller, Kevin Lane \& Lehmann, Donald R. (2006). Brands and Branding: Research Findings and Future Priorities. Marketing Science, Vol. 25, No. 6, (November-December), pp.740-759.

Keller, Kevin Lane (2003). Brand Synthesis: The Multidimensionality of Brand Knowledge » Journal of Consumer Research, Vol.29, (March), pp.595-600

Keller, Kevin Lane (1993). Conceptualizing, Measuring and Managing Customer-Based Brand Equity. Journal of Marketing, Vol.57, No. 1, pp.1-22.

Kim, Hong-bumm., Kim, Woo Gon \& An, Jeong A. (2003). The effect of consumer-based brand equity on firms' financial performance. Journal of Consumer Marketing, Vol. 20, Iss: 4, pp. 335-351

King, Ceridwyn \& Grace, Debra (2009) Employee Based Brand Equity: A Third Perspective. Services Marketing Quarterly, Vol. 30, No. 2, pp.122-147.

Kotler, Philip. Armstrong, Gary., Saunders, John \& Wong, Veronica (1999). Principles of Marketing Second edition, Prentice Hall/Europe.

Krishnan, H.S (1996) Characteristics of memory associations: a consumer-based brand equity perspective » International Journal of Research in Marketing, Vol.13 Iss: 4, pp.389-405

Levy, Sidney J. (1959). Symbols for Sale. Harvard Business Review. Vol.37 (March-April), 117-124.

Low, George. S and Lamb, Jr Charles. (2000) The measurement and dimensionality of brand associations. Journal of Product and Brand Management, Vol. 9, No. 6, pp.350-368.

Morandin, Gabriele., Bagozzi, Richard P., Bergami, Massimo. (2013). Brand community membership and the construction of meaning. Scandinavian Journal of Management, Vol. 29, pp.173-183.

Motameni, Reza. \& Shahrokhi, Manuchehr. (1998). Brand Equity Valuation: A Global Perspective. Journal of Product \& Brand Management, Vol. 7 Iss: 4, pp.275-290.

MSI. (2004). Research Priorities 2004-2006. Marketing Science Institute, Cambridge, MA.

Na, Woon Bong., Marshall, Roger \& Keller, Kevin Lane. (1999). Measuring brand power: validating a model for optimizing brand equity. Journal of Product \& Brand Management, Vol. 8 No. 3, pp. 170-184

Netemeyer, Richard G., Krishnan, Balaji., Pullig, Chris., Wang, Guangping., Yagci, Mehmet., Dean, Dwane., Ricks, Joe \& Wirth, Ferdinand. (2004) Developing and validating measures of facets of customer-based brand equity Journal of Business Research, Vol. 57, pp.209-224.

Pappu, R., Quester, P.G. \& Cooksey, R.W. (2005). Consumer-based brand equity: improving the measurement-empirical evidence. Journal of Product and Brand Management, Vol.14, No. 3, pp.143-154.

Park, C. Whan., MacInnis, Deborah J., Priester, Joseph., Eisingerich, Andreas B. \& Iacobucci, Dawn. (2010). Brand Attachment and Brand Attitude Strength : Conceptual and Empirical Differentiation of Two Critical Brand Equity Drivers. Journal of Marketing, Vol. 74, (Nov), pp.1-17.

Park, Chan Su., \& V. Srinivasan. (1994). A survey-based method for measuring and understanding brand equity and its extendability. Journal of marketing research, Vol. 31, (May), pp.271-288.

Richins, Marsha L. (1983). Negative Word-of-Mouth by Dissatisfied Consumers: A Pilot Study. Journal of Marketing, Vol 47, No.1, (Winter), pp.68-78.

Simon, Carol J. \& Sullivan, Mary W (1993). The Measurement and Determinants of Brand Equity: a Financial Approach. Marketing Science, Vol.12, (Winter), pp.28-52.

Teo, Raymond \& Soutar, Geoffrey N. (2012). Word of Mouth Antecedents in an Educational Context: a Singaporean Study. International Journal of Educational Management, Vol. 26 Iss: 7, pp. 678-695

Thomson, Matthew., MacInnis, Deborah J. \& Park, C. Whan. (2005). The Ties That Bind: Measuring the Strength of Consumers' Emotional Attachments to Brands. Journal of Consumer Psychology, Vol.15, No.1, pp.77-91.

Walfried Lassar, Banwari Mittal, Arun Sharma, (1995). Measuring customer-based brand equity. Journal of Consumer Marketing, Vol.12 Iss: 4 pp. 11-19.

Walliser, Elisabeth. (2001). La mesure comptable des marques. (Version Numérique 2009), Vuibert, France.

Westbrook, R.A. (1987). Product/consumption-based affective responses and post-purchase processes. Journal of Marketing Research, Vol. 24, August, pp. 258-70.

Yoo, Boonghee \& Donthu, Naveen. (2001). Developing and validating a multidimensional consumer-based brand equity scale. Journal of Business Research, Vol.52, pp.1-14.

Yoo, Boonghee. Donthu, Naveen. \& Lee, Sungho (2000) An Examination of Selected Marketing Mix Elements and Brand Equity. Journal of the Academy of Marketing Science, Vol. 28, No. 2, pp.195-211.

Zeithaml, Valarie A. (1988). Consumer Perceptions of Price, Quality, and value: A Means-End Model and Synthesis of Evidence. Journal of Marketing, Vol.52, (July), pp.2-22. 